\title{
PENGARUH DISIPLIN, KEMAMPUAN, DAN INSENTIF TERHADAP MOTIVASI DAN KINERJA KARYAWAN PADA PT. INDOSATOOREDO, TbK BANDAR LAMPUNG
}

\author{
Desmon(desmon@umitra.ac.id) \\ Andi Surya(Stie@umitra.ac.id) \\ Armalia Reny WA(Stie@umitra.ac.id) \\ Yudhinanto CN(Yudhi@ umitra.ac.id) \\ Maria Septijantini Alie (maria_alie@umitra.ac.id)
}

\begin{abstract}
Penelitian ini bertujuan untuk mengetahui pengaruh disiplin, kemampuan, dan insentif terhadap motivasi dan kinerja karyawan, dan untuk mengetahui pengaruh motivasi terhadap kinerja karyawan pada PT. Indosatoredo, Tbk Bandar Lampung. Penelitian ini menggunakan sampel jenuh dengan menggunakan seluruh karyawan pada PT. Indosatoredo, Tbk Bandar Lampung sebanyak 32 sampel. Metode analisis dari penelitian ini menggunakan analysis jalur (Path Analysis). Berdasarkan hasil analisis ditemukan bahwa disiplin, kemampuan, dan insentif secara bersama-sama berpengaruh positif terhadap motivasi kerja dan kinerja karyawan dan motivasi berpengaruh positif dan signifikan terhadap kinerja karyawan. Disiplin berpengaruh positif dan signifikan terhadap kinerja karyawan, kemampuan berpengaruh positif dan signifikan terhadap kinerja karyawan, insentif berpengaruh positif dan signifikan terhadap kinerja karyawan dan motivasi sebagai perantara pengaruh disiplin, kemampuan, dan intensif terhadap kinerja karyawan. Berdasarkan hasil penelitian, perusahaan PT. Indosatoredo, Tbk Bandar Lampung sebaiknya membudayakan disiplin, memberikan kesempatan peningkatan kemampuan dan pemberian insentif secara adil, dan memotivasi karyawan dengan promosi jabatan.
\end{abstract}

\section{Kata Kunci : disiplin, kemampuan, insentif, motivasi, dan kinerja} karyawan

\section{PENDAHULUAN}

Setiap perusahaan selalu berharap untuk mencapai produktivitas yang tinggi dan bertujuan untuk mencapai keuntungan maksimal dengan biaya yang minimal. Dengan adanya program yang telah disusun dan lengkapnya fasilitas yang tersedia tidak akan ada artinya apabilla tanpa didukung oleh tenaga kerja yang handal. PT. Indosatooredoo Tbk, Bandar Lampun merupakan sebuah perusahaan penyelenggara jasa telekomunikasi International di Indonesia. Pada tahun 1967 didirikan sebagai perusahaan penanam mdal asing pertama di Indonesia yang menyediakan layanan telekomunikasi Internasional, PT. Indosatooredoo Tbk, Bandar Lampung memiliki karyawan berjumlah 32 karyawan. Perusahaan sangat memerlukan sumber daya manusia yang handal dan berkopenten untuk menunjang pelaksanaan kerja. Kinerja karyawan merupakan kunci keberhasilan dalam pencapaian perusahaan sesuai dengan visi dan misi nya untuk menjadikan penyelenggara jaringan dan mengembangkan produk layanan dan sosial yang inovatif dan berkualitas untuk memberikan manfaat terbaik bagi pelanggan. Faktor yang mempengaruhi kinerja karyawan yaitu kedisiplinan, kemampuan, insentif dan motivasi.

Disiplin kerja merupakan alat penggerak karyawan, bahwa disiplin kerja yang tinggi harus diterapkan dalam perusahaann karena dengan mendisiplinkan karyawan akan dapat 
meningkatkan kinerja karywan. Akan tetapi sebaliknya apabila disiplin tidak ditegakkan atau tidak dijalankan oleh semua karyawan maka kinerja karyawan akan menurun. Kemampuan adalah potensi yang dimilki oleh karyawan untuk melaksanakan tugas atau pekerjaan didalam perusahaan. Kemampuan kerja karyawan yang memadai akan berdampak pada hasil perusahaan yang baik juga. Pemberian insentif adalah salah satu kompensasi atau imbalan yang diberikan kepada karywan dan tidak ada kaitannya dari upah dan gaji, atas dasar menghasilkan produk yang melebihi target tertentu. Pemberian insentif sangat perlu untu meningkatkan kinerja karyawan dan pendapatan karywan.

Motivasi merupakan pendorong seseorang untuk melakukan aktifitasnya dengan motif utnuk mempunyai tujuan tertentu yang ingin dicapai. Dengan adanya motivasi yang tinggi diharapkan akan meningkatkan kinerja karyawan, apabila tidak ada motivasi dalam perusahaan akan berdampak pada kinerja karywan yang menurun. Mengingat faktor-faktor dalam penilain kinerja karyawan pada PT. Indosatooredoo Tbk, Bandar Lampung sangat penting didalam perusahaan. Berdasarkan uraian diatas maka penulis tertarik untuk melakukan penelitian dengan judul : “ Faktor-faktor Yang Mempengaruhi Motivasi dan Dampaknya Terhadap Kenerja Karyawan Pada PT. Indosatooredoo Tbk, Bandar Lampung Tahun'.

\section{Perumusan Masalah}

Berdasarkan latar belakang tersebut, maka rumusan masalah dalam penelitian ini adalah sebagai berikut :

1. Berapa besar pengaruh variabel disiplin kerja, kemampuan, dan insentip secara parsial atau sendiri-sendiri terhadap variabel motivasi ?

2. Berapa besar pengaruh variabel disiplin kerja, kemampuan, dan insentip secara simultan atau bersama-sama terhadap variabel motivasi ?

3. Berapa besar pengaruh variabel disiplin kerja, kemampuan, insentip. Dan motivasi secara parsial atau sendiri-sendiri terhadap variabel kenerja pegawai ?

4. Berapa besar pengaruh variabel disiplin kerja, kemampuan, insentip, dan motivasi secara simultan atau bersama-sama terhadap variabel kinerja pegawai ?

\section{Tujuan Penelitian}

Tujuan yang akan dicapai dalam penelitian ini adalah:

1. Mengetahui besar pengaruh variabel disiplin kerja, kemampuan, dan insentip secara parsial atau sendiri-sendiri terhadap variabel motivasi kerja.

2. Mengetahui besar pengaruh variabel disiplin kerja, kemampuan, dan insentip secara simultan atau bersama-sama terhadap variabel motivasi kerja.

3. Mengetahui besar pengaruh variabel disiplin kerja, kemampuan, insentip, dan motivasi secara parsial atau sendiri-sendiri terhadap variabel kinerja pegawai.

4. Mengetahui besar pengaruh variabel disiplin kerja, kemampuan, insentip, dan motivasi secara simultan atau bersama-sama terhadap variabel kinerja pegawai.

\section{Manfaat penelitian}


Dari hasil penelitian diharapkan akan memberikan manfaat sebagai berikut:

1. Manfaat secara teoritis

a. Untuk menambah dan memperluas wawasan pengetahuan tentang sumber daya manusia yang berkaitan dengan motivasi, disiplin, lingkungan, efektivitas dan produktivitas kerjadan.

b. Hasil penelitian ini diharapkan dapat bermanfaat sebagai bahan ilmiah yang dapat berguna bagi pihak-pihak yang membutuhkan.

2. Manfaat secara praktis

a. Bagi penulis untuk mengaplikasikan ilmu statistik yang dapat di bangku kuliah serta untuk mengetahui kondisi yang sebenarnya mengenai motivasi, disiplin, lingkungan, efektivitas,produktivitas kerja.

b. Bagi perusahaan dapat memberikan sumbangan pemikiran bagi pimpinan perusahaan dalam mengambil kebijaksanaan dengan usaha peningkatan motivasi, disiplin, lingkungan, efektivitas, produktivitas kerja.

\section{KERANGKA TEORITIS}

\section{Disiplin Kerja}

Menurut Singodimejo dalam (Sutrisno, 2014:86) disiplin kerja adalah sikap kesediaan dan kerelaan seseorang untuk mematuhi dan menaati norma-norma peraturan yang berlaku disekitarnya. Dengan disiplin kerja yang baik akan mempercepat tujuan perusahaan, sedangkan dengan disiplin kerja yang merosot akan menjadi penghalang dan menghambat untuk mencapai tujuan perusahaan. Faktor yang memepengaruhi disiplin kerja adalah frekuensi kehadiran, tingkat keaspadaan, ketaatan pada standar kerja ketaatan pada peraturan kerja dan etika kerja. Tujuan disiplin kerja untuk memotivasi karyawan, mempertahankan hubungan saling menghormati, meninkatkan kinerja karyawna dan pendisiplinan.

\section{Kemampuan}

Menurut Robbins (2003:40) dalam (Wibowo, 2015:93) Kemampuan (ability) menunjukkan kepastian individu untuk mewujudkan berbagai tugas dalam pekerjaan. Merupakan penilaian terhadap apa yag dapat dilakukan oleh seseorang sekarang ini. Kemampuan menyuluruh individu pada dasarnya dibentuk oleh 2 kelompok faktor yaitu : Intellectual dan Physical Abilities. Kemampuan atau kompetensi adalah karakteristik yang mebdasarai seseorang berkaitan dengan efektifitas kinerja individu dalam pekerjaannya atau karakteristik dasar yang dijadikan acua, efektif atau berkinerja prima atau superior di tempat kerja pada situasi tertentu (Moeheriono, 2012:2). Menurut Robbins (2013 :56) dalam (Wibowo. 2015: 102) menyatakan bahwa kemampuan keseluruhan seorang individu pada dasarnya terdiri atas 2 kelompok faktor, yaitu kemampuan pengetahuan dan kemampuan fisik.

\section{Insentif}


Insentif adalah salah satu kompensasi atau imbalan yang diberikan kepada karyawan dan tidak kaitannya dari upah dan gaji, atas dasar menghasilkan produk melebihi target tertentu. Apabila insentif yang diterima bukan atas dasar melebihi target yang ditentukkan, melainkan atas dasar individu maka pekerja tersebut bukan meningkatkna prestasi justru akan membuat pekerja tersebut semakin malas. Seperti absensi kehadiran yang semaki buruk, menurunnya prosuktifitas dan kinerja karyawan. Hasibuan (2013:118) Insentif adalah tambahan balas jasa yang diberikan kepada karyawna yang prestasinya diatas prestasi standar. Insentif ini merupakan alat yang digunakan pendukung perinsip asil dalam pemberian kompensasi. Menurut Handoko (2002:56) dalam (Wibowo, 2015:89) ada enam faktor yang mempengaruhi insentif, yaitu : Kinerja, Lama kerja, Senoritas, Kebutuhan, Keadilan dan Kelayakkan, dan Evaluasi Jabatan

\section{Motivasi}

Menurut Sutrisno (2014:109) motivasi adalah suatu faktor yang mendorong seseorang untuk melakukan suatu aktifitas tertentu, oleh karena itu motivasi seringkali diartikan pula diartikan pula sebagai faktor pendorong perilaku seseorang setiap aktifitas yang dilakukan seseorang pasti memiliki suatu faktor yang mendorong aktifitas tersebut. Biasanya seorang karyawan untuk mencapai target tertentu pasti ada faktor-faktor yang mendorong atau memberikan semngat faktor tersebut. Kebutuhan atau keinginan seseorang tidak akan sama antara yang satu dengan yang lain. Keinginan dan kebutuhan yang beragam ini terjadi karena proses menta dan karakteristik yang terjadi pada diri seorang karyawan. Faktor yang mempengaruhi motivasi adalah: faktor internal dan faktor ekternal.

\section{Kinerja Karyawan}

Menurut Mangkunegara (2013:67), istilah kinerja berasal dari Job Performance dan Actual Performance ( prestasi kerja atau prestasi sesungguhnya yang dapat dicapai seseorang.maka pengertian kinrja adalah hasil kerja secara aktualitas untuk kuantitas yang dicapai oleh seorang pegawai dalam melaksanakan tugasnya sesuai dengan tanggung jawab yang diberikan kepadanya. Menurut Wibowo (2015:7) mengatakna bahwa kinerja adalah sebagai hasil kerja atau prestasi kerja. Namun, sebenernya mempunyai arti yang luas bukan hanya hasil kerja, tetapi termasuk bagaimana proses pekerjaan berlangsung. Penilaian kinerja adalah evaluasi yang sistematis terhadap pekerjaan yang telah dilakukan oleh karyawan dan ditunjukkan untuk pengembangan. Tentang penilaian kinerja ditengah kompetisi yang glonal perusahaan menuntut kinerja yang tinggi dari setiap karyawan Simamura dalam (Mulyadi, 2015:109).

\section{KERANGKA KONSEP PENELITIAN}

Penelitian ini dilakukan untuk mengkaji pengaruh variabel disiplin kerja, kemampuan, dan insentip terhadap motivasi dan kenerja. Studi dilakukan pada PT. Indosatooredoo Tbk, Bandar Lampung, faktor-faktor yang diduga berpengaruh kepada kinerja karyawan antara lain disiplin kerja, kemampuan, insentip, dan motivasi. Meningkatkan disiplin kerja, kemampuan, pemberian intensip, dan menumbuhkan motivasi 
kerja karyawan dapat memberikan keuntungan pada perusahaan baik industri maupun nasional.

Hasil penelitian ini mempunyai pengaruh positif bahwa dengan menciptakan dan meningkatkan disiplin kerja karyawan yang baik merupakan bagian yang penting dari manajemen organisasi untuk menjaga kondisi yang menguntungkan bagi perusahaan. Penelitian ini merujuk pada Nurcahyo (2011) bahwa disiplin kerja berpengaruh positif terhadap kinerja karyawan, artinya meningkatkan dan menjaga displin karyawan dapat meningkat kinerja karyawan pada perusahaan.

Dalam penelitian ini kemampuan juga merupakan salah satu faktor yang berpengaruh pada motivasi dan kinerja karyawan. Kemampuan adalah potensi yang dimilki oleh karyawan untuk melaksanakan tugas atau pekerjaan didalam perusahaan. Sachroni (2013) dalam penelitiannya menyimpulkan bahwa faktor-faktor motivasi, kemampuan, persepsi peran dan situasional organisasi secara berpengaruh terhadap kinerja karyawan. Hal ini sejalan dengan penelitian Anton (2011) yang menunjukkan bahwa hasil uji hipotesis kemampuan mempunyai pengaruh positif terhadap kinerja karyawan.

Sedangkan untuk variabel Insentif penelitian ini mengacu pendapat pada penelitian Suprihati (2014) yang menyimpulkan bahwa motivasi, insentif dan lingkungan kerja berpengaruh secara signifikan terhadap kinerja karyawan. Menurut Hasibuan (2013:118) Insentif adalah tambahan balas jasa yang diberikan kepada karyawna yang prestasinya diatas prestasi standar. Insentif ini merupakan alat yang digunakan pendukung perinsip dalam pemberian kompensasia. Menurut Pengabean dalam (Mulyadi, 2015:82) insentif adalah kompensasi yang mengkaitkan gaji dengan prosuktivitas, insentif merupakan penghargaan dalam bentuk uang yang berdasarkan kepala mereka yang dapat bekerja melalui standarstandar yang telah ditentukkan. Tujuan utama dalam pemberian insentif adalah untuk memberikan tanggung jawab penuh kepada karyawan dan memotivasi karyawan tersebut mau meningkatkan produktifitas dan mengarah ketujuan organisasi sehingga perusahaan akan dapat meningkatkan keuntungan serta dapat mempertahankan kelangsungan hidup perusahaan.

Dalam penelitian ini motivasi juga mempengaruhi kinerja karyawan, hal ini mengacu pada penelitian Suprihati (2014) yang menyimpulkan bahwa motivasi, insentif dan lingkungan kerja berpengaruh secara signifikan terhadap kinerja karyawan. Motivasi adalah suatu faktor yang mendorong seseorang untuk melakukan suatu aktifitas tertentu, oleh karena itu motivasi seringkali diartikan pula sebagai faktor pendorong perilaku seseorang setiap beraktifitas yang dilakukan seseorang pasti memiliki suatu faktor yang mendorong aktifitas tersebut (Sutrisno, 2014:109). Menurut Mulyadi (2015:93), tujuan pemberian motivasi kerja kepada karyawan antara lain meningkatkan moral dan kepuasan kerja, meningkatkan produktiditas kerja karyawan, mempertahankan kestabilan karyawan perusahaan, meningkatkan kedisiplina karyawan, mengefektifkan pengadaan karyawan, menciptakan suasana dan hubungan kerja yang baik, meningkatkan loyalitas, kratifitas dan partisipasi karyawan, meningkatkan tingkat, mesejahteraan karyawan, mempertinggi rasa 
tanggung jawab karyawan terhadap tugas-tugasnya, dan meningkatkan efesiensi penggunaan alat-alat bahan baku.

Selain motivasi kerja, implementasi kinerja karyawan secara konseptual kinerja karyawan didefinisikan sebagai hasil kerja secara kuantitas, kualitas dan ketepatan waktu yang dicapai seseorang karyawan dalam melaksanakan tugasnya sesuai tanggung jawab yang diberikan kepadanya. Atas dasar pemikiran di atas dapat digambarkan kerangka konseptual dalam penelitian sebagaimana dapat dilihat pada Gambar 1 sebagai berikut:

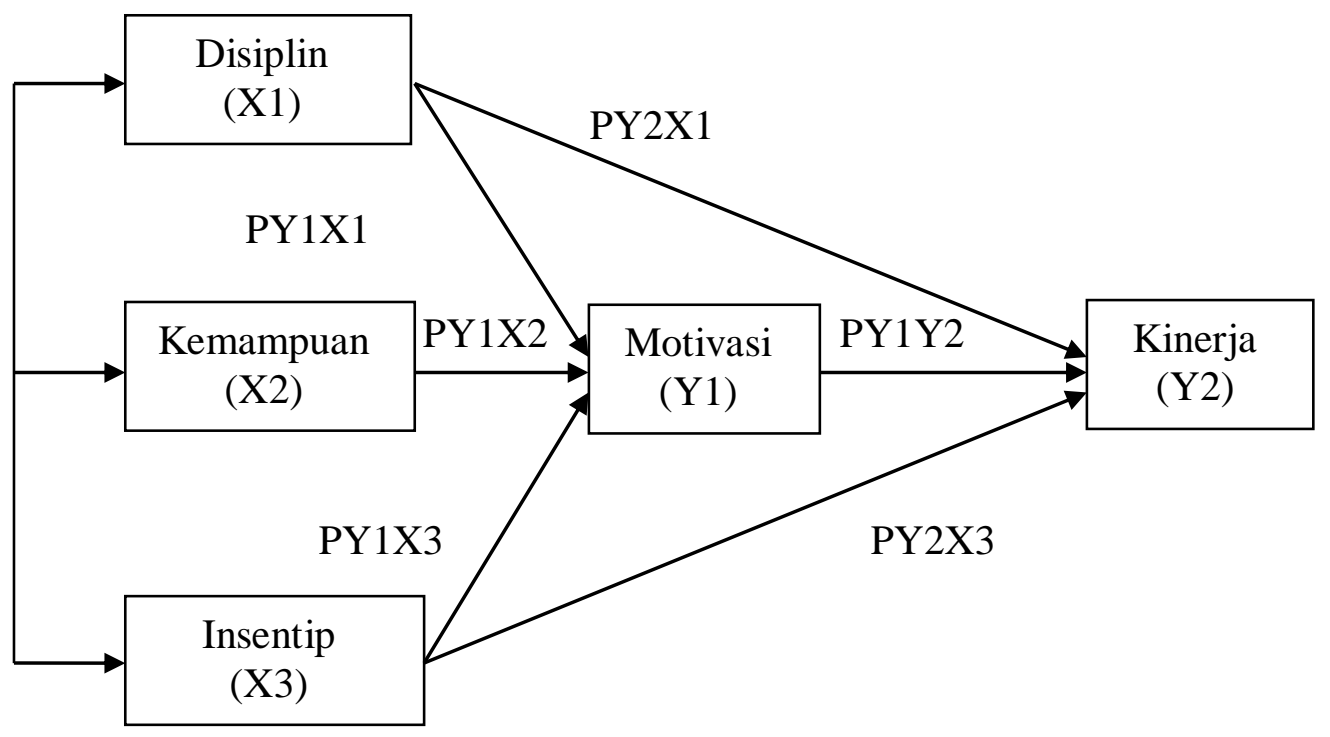

Gambar 1. Kerangka Konsep Penelitian

\section{HIPOTESIS}

Berdasarkan model hipotesa penelitianyang telah dibuat, maka hipotesis yang diajukan dalam penelitian ini adalah:

Hipotesis 1 : Variabel disiplin kerja, kemampuan, dan insentip secara parsial atau sendirisendiri terhadap variabel motivasi.

Hipotesis 2 : Variabel disiplin kerja, kemampuan, dan insentip secara parsial atau sendirisendiri terhadap variabel motivasi.

Hipotesis 3 : Variabel disiplin kerja, kemampuan, insentip. Dan motivasi secara parsial atau sendiri-sendiri terhadap variabel kenerja pegawai.

Hipotesis 4 : Variabel disiplin kerja, kemampuan, insentip, dan motivasi secara simultan atau bersama-sama terhadap variabel kinerja pegawai.

\section{METODOLOGI PENELITIAN}

\section{Desain Penelitan}


Desain penelitian ini menggunakan metode penelitian survei dengan pendekatan kuantitatif. Variabel bebas yang digunakan dalam penelitian ini variabel disiplin kerja (X1), kemampuan (X2), insentif (X3), dan motivasi (Y1) sebagai variabel intervening. Sedangkan variabel terikat yang digunakan adalah variabel Kinerja Pegawai (Y2). Untuk mempelajari hubungan dan pengaruh antara variabel bebas dan variabel terikat dugunakan analisis jalur atau perth analysis (Sugiyono, 2015:15).

\section{Lokasi dan waktu Penelitian}

Lokasi penelitian dialaksanakan pada PT. Indosatooredoo Tbk cabang lampung di Bandar Lmapung,sedangkan waktu penelitian dilakukan pada bulan Maret sampai Juli 2017.

\section{Populasi dan Sampel Penelitian}

Populasi yang dalam penelitian ini adalah seluruh karyawan pada PT. Indosatooredoo Tbk cabang lampung di Bandar Lampung yang berjumlah 32 karyawan baik lakilakimaupun perempuan. Pengambilan sampel menggunakan teknik sampling jenuh, dimana semua populasi diambil seluruhnya untuk menjadi sempel (Sugiyono, 2015:60), sehingga jumlah sampel dalam penelitian ini sebanyak 32 orang.

\section{Pengumpulan Data}

Teknik pengumpulan data adalah langkah yang cukup penting dalam penelitian, karena tanpa menggunakan teknik yang tepat, maka peneliti tidak akan memperoleh data yang sesuai dengan standar yang ditetapkan. Dalam penelitian ini teknik pengumpulan data yang digunakan adalah studi pustaka dan wawancara dengan bantuan kuisioner yang sudah disiapkan sebelumnya.

\section{Definisi Operional Variabel}

Definisi operasional variabel-variabel yang akan diteliti merupakan cara untuk mempermudah mengukur variabel penelitian. Selain itu juga memberi batasa-batasan yang jelas pada objek yang akan diteliti.

\section{Disiplin Kerja (X1)}

Disiplin kerja adalah sebagai pelaksanaan manajemen untuk memperteguh pedoman-pedoman organisasi. Dalam suatu organisasi seorang pimpinan memerlukan alat untuk komunikasi dengan karyawannya mengenai tingkah laku para karyawan, dan bagaimana memperbaiki perilaku para karyawan menjadi lebih baik lagi, dan disiplin kerja yang diterapkan alat komunikasi pimpinan (Mangkunegara, 2013:129). Konsep disiplin kerja dalam penelitian ini diukur dengan indikator yaitu integritas, mematuhi peraturan organisasi, mematuhi jam kerja dan manajemen waktu.

\section{Kemampuan (X2)}

Kemampuan atau kompetensi adalah karakteristik yang mendasari seseorang berkaitan dengan efektifitas kinerja individu dalam pekerjaannya atau karakteristik dasar yang dijadikan acuan, efektif atau kinerja prima atau superior di tempa kerja pada situasi 
tertentu (Moeheriono, 2010:2). Konsep kemampuan kerja dalam penelitian ini diukur dengan indikator yaitu kemampuan intlektual dan kemampuan fisik.

\section{Insentif (X3)}

Menurut Hasibuan (2013:118) Insentif adalah tambahan balas jasa yang diberikan kepada karyawna yang prestasinya diatas prestasi standar. Insentif ini merupakan alat yang digunakan untuk pendukung perinsip hasil dalam pemberian kompensasia. Menurut Mulyadi, (2015:82) insentif adalah kompensasi yang mengkaitkan gaji dengan produktivitas, insentif merupakan penghargaan dalam bentuk uang yang berdasarkan individu mereka yang dapat bekerja melalui standar-standar yang telah ditentukkan. Konsep insentif dalam penelitian ini diukur dengan indikator yaitu kinerja, lama kerja, senioritas, kebutuhan, keadilan dan kelayakan serta evaluasi jabatan.

\section{Motivasi (Y1)}

Menurut Sutrisno (2014:109) motivasi adalah suatu faktor yang mendorong seseorang untuk melakukan suatu aktifitas tertentu, oleh karena itu motivasi seringkali diartikan pula diartikan pula sebagai faktor pendorong perilaku seseorang setiap aktifitas yang dilakukan seseorang pasti memiliki suatu faktor uang mendorong aktifitas tersebut. Sedangkan menurut Hasibuan dalam (Sutrisno, 2014:110) motivasi adalah suatu perangsang keinginan dan daya penggerak kemauana bekerja seseorang setiap motif mempunyai tujuan tertentu yang ingin dicapai. Konsep motivasi dalam penelitian ini diukur dengan indikator yaitu motivasi internal dan motivasi eksternal.

\section{Kinerja Karyawan (Y2)}

Menurut Moeheriono (2012:69), arti kata kinerja berasal dari kata job performance dan disebut juga actual performance atau prestasi kerja atau prestasi seseungguhnya yang telah dicapai oleh seseorang karyawan. Kinerja atau performance merupakan gambaran mengenai tingkat pencapaian suatu pelaksanaan suatu rogram kiatan atau kebijakan dalam mewujudkan sasaran, tujuan, visi da misi organisasi yang dituangkan melalui perencanaan suatu strategi organissi. Menurut Wibowo (2011:7) mengatakna bahwa kinerja adalah sebagai hasil kerja tau prestasi kerja. Namun, sebenernya mempunyai arti yang luas bukan hanya asil kerja, tetapi termasuk bagaimana proses pekerjaan berlangsung. Konsep motivasi dalam penelitian ini diukur dengan indikator yaitu kuantitas pekerjaan, kualitas pekerjaan, ketepatan waktu, kehadiran, kempuan bekerja sama.

\section{Analisis Data}

Metode analisis yang digunakan untuk menguji hipotesis dalam penelitian ini menggunakan teknik analisis jalur (path analysis) yang terstandarisasi dan dihitung melalui program SPSS. Jadi Model path analysis digunakan untuk menganalisis pola hubungan antar variabel dengan tujuan untuk mengetahui pengaruh langsung maupun tidak langsung seperangkat variabel bebas (independen) terhadapvariabel terikat (dependen). Menurut Sugiono (2013:130) manfaat lain model path analysis adalah untuk: (1) Penjelasan (explanation) terhadap fenomena yang dipelajari atau permasalahan yang diteliti; (2) Prediksi nilai variabel terikat (Y) berdasarkan nilai variabelbebas $(\mathrm{X})$, dan prediksi dengan 
path analysis ini bersifat kualitatif; (3) Faktor determinan yaitu penentuan variabel bebas (X) mana yang berpengaruh dominan terhadap variabel terikat $(\mathrm{Y})$, juga dapat digunakan untuk menelusuri (jalur-jalur) pengaruh variabel bebas (X) terhadap variabel terikat (Y); (4) Pengujian model, menggunakna theory triming, baik untuk uji realibilitas (uji keajekan) konsep yang sudah ada ataupun uji pengembangan konsep baru. Selanjutnya Sugiono (2013:128) menjelaskan asumsi yang mendasari analisis jalur yaitu: (1) Pada model path analysis, hubungan antar variabel adalah bersifat linier adaptif dan bersifat normal; (2) Hanya sistem aliran kausal ke satu arah artinya tidak ada arah kausalitas yang terbalik; (3) Variabel terikat (devenden) minimal dalam skala ukur interval dan ratio; (4) Menggunakan sampel probability sampling yaitu teknik pengambilan sampel untuk memberikan peluang yang sama pada setiap anggota populasi untuk dipilih menjadi anggota sampel; (5) Observed variables diukur tanpa kesalahan (instrumen pengukuran valid dan reliable) artinya variabel yang diteliti dapat diobservasi secara langsung; (6) Model yang dianalisis dispesifikasikan (diidentifikasi) dengan benar berdasarkan teori-teori dan konsep-konsep yang relevan artinya model teori yang dikaji atau diuji dibangun berdasarkan kerangka teoritis tertentu yang mampu menjelaskan hubungan kausalitas antar variabel yang diteliti.

Koefisien jalur dihitung dengan dua persamaan struktural yaitu persamaan regresi yang menunjukkan hubungan yang dihipotesiskan. Dalam hal ini ada dua persamaan struktural tersebut adalah :

$$
\mathrm{Y} 1=P_{Y 1} \mathrm{X} 1+P_{Y 1} \mathrm{X} 2+P_{Y 1} \mathrm{X} 3+\varepsilon \mathrm{i}
$$

Keterangan :

$$
\begin{aligned}
& \mathrm{Y} 1=\text { Motivasi } \\
& \mathrm{X} 1=\text { Disiplin Kerja } \\
& \mathrm{X} 2=\text { Kemampuan } \\
& \mathrm{X} 3=\text { Insentif } \\
& \mathrm{P}=\text { Koefisien Jalur } \\
& \varepsilon \quad=\text { Error } \\
& \mathrm{Y} 2=P_{Y 2} \mathrm{X} 1+P_{Y 2} \mathrm{X} 2+P_{Y 2} \mathrm{Y} 1+\varepsilon \mathrm{i}
\end{aligned}
$$

Keterangan :

$$
\begin{aligned}
& \mathrm{Y} 2=\text { Kinerja Karyawan } \\
& \mathrm{X} 1=\text { Disiplin Kerja } \\
& \mathrm{X} 2=\text { Intensif } \\
& \mathrm{Y} 1=\text { Motivasi } \\
& \mathrm{P}=\text { Koefisien Jalur } \\
& \varepsilon \quad=\text { Error }
\end{aligned}
$$

\section{HASIL PENELITIAN DAN PEMBAHASAN}




\section{Karaktristik Responden}

Jumlah responden yang terlibat pada penelitian ini berjumlah 32 responden karyawan pada PT. Indosatooredo, Tbk cabang Bandar Lampung. Karakteristik responden pada penelitian ini terdiri atas usia, jenis kelamin, pendidikan terakhir dan pengalaman bekerja. Gambaran karakteristik responden berikut ini sudah menggambarkan dari populasi yang ada karena seluruh populasi diambil menjadi sampel. Sedangkan keragaman karakteristik responden bisa berperan menjadi sumber pembeda penilaian terhadap keempat variabel yang diteliti. Karakteristik responden sebagian besar responden berusia kurang dari 30 tahun yaitu berjumlah 18 responden $(56,25 \%)$ sedangkan sisanya sebanyak 14 responden $(43,75 \%)$ adalah berusia lebih dari 30 tahun.Jumlah responden berdasarkan jenis kelamin adalah lakilaki dengan jumlah 23 responden $(71,87 \%)$, sedangkan untuk perempuan berjumlah 9 responden $(28,13 \%)$. Tingkat pendidikan karyawan didominasi oleh pendidikan sarjana S-1 dengan jumlah sebanyak 21 responden $(65,63 \%)$ dan sisanya sebanyak 11 responden $(34,47 \%)$ adalah lulusan SMA.

Karaktristik responden berdasarkan pengalaman bekerja menunjukkan bahwa responden memiliki pengalaman bekerja di atas lima tahun sebanyak 17 responden $(53,23 \%)$,sedangkan sisanya sebanyak 15 responden $(47,67 \%)$ memiliki pengalaman kurang dari lima tahun. Operasional kerja di lingkungan perusahaan jasa telekomunikasi mencakup kegiatan perumusan program, target kerja serta evaluasi kerja, sehingga pada konteks ini dibutuhkan kemampuan karyawan untk bisa bekerja secara individu maupun team. Sejalan dengan perkembangan yang dialami oleh industri imformasi dan telekomunikasi, maka kebutuhan tenaga kerja yang memiliki komptensi tinggi juga menjadi bertambah pesat sejalan dengan pertumbuhan dan perkembangan industri imformasi dan telekomunikasi tersebut.

\section{Hasil Analisis Jalur}

Pendugaan terhadap seluruh koefisien jalur untuk variabel yang dimasukkan dalam model penelitian ini dapat dilihat pada Tabel 1 berikut ini :

Tabel 1. Hasil Uji Koefisien Jalur

\begin{tabular}{|c|c|c|c|}
\hline Variabel Independen & Variabel Dependen & $\begin{array}{c}\text { Koeefisien } \\
\text { Regresi }\end{array}$ & Siqnifikansi \\
\hline Disiplin Kerja & Motivasi & 0,494 & 0,004 \\
\hline Kemampuan & Motivasi & 0,375 & 0,039 \\
\hline Insentif & Motivasi & 0,135 & 0,048 \\
\hline Disiplin Kerja & Kinerja Karyawan & 0,197 & 0,024 \\
\hline Insentif & Kinerja Karyawan & 0,485 & 0,000 \\
\hline Motivasi & Kinerja Karyawan & 0,175 & 0,026 \\
\hline
\end{tabular}

Sumber : Data Primer Diolah, 2017. 
Pada Tabel 1 di atas menjelaskan bahwa dari enam jalur pada model hipotesis tidak semua jalur adalah signifikan. Peran dominan terhadap motivasi kerja bersumber dari disiplin kerja, sedangkan terhadap kinerja karyawan pengaruh dominan bersumber dari Insentif. Secara khusus kedua jalur dominan ini menjadi menarik karena menjadi penentu tingginya kinerja karyawan. Untuk lebih jelasnya hasil analisis jalur secara keseluruhan dapat disajikan pada Gambar 2.

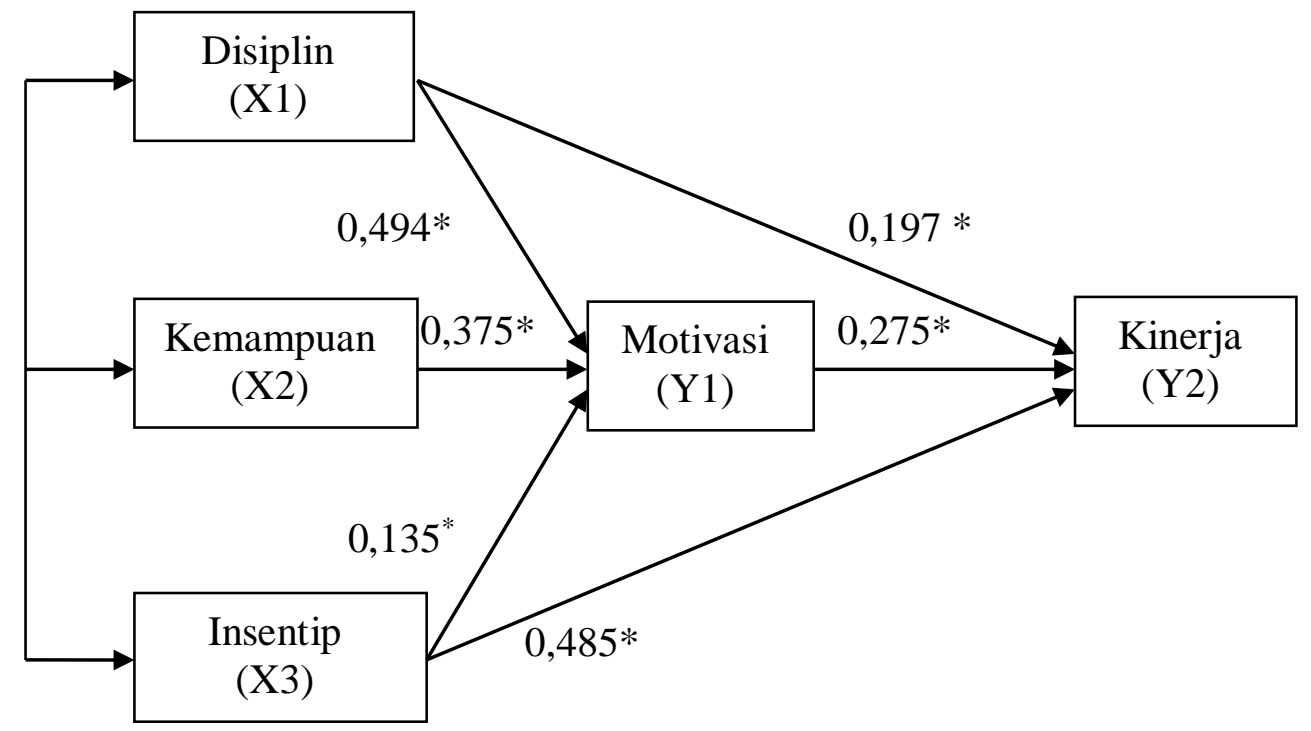

Gambar 2. Hasil Analisis Jalur

Keterangan : $\quad *=$ signifikan pada taraf nyata $\alpha=0,05$

\section{Ketepatan Model}

Ketepatan model hipotesis dari data penelitian diukur dari hubungan dua koefisien determinasi (R2) di kedua persamaan. Pada persamaan pertama diperoleh nilai R21 sebesar 0,662 dan R22 sebesar 0,848 pada Persamaan kedua.

Hasil ketepatan model adalah :

$$
\begin{aligned}
\mathrm{R} 2 \text { model } & =1-(1-\mathrm{R} 21)(1-\mathrm{R} 22) \\
& =1-(1-0,662)(1-0,848) \\
& =1-(0,338)(0,152) \\
& =1-0,152 \\
= & 0,848 \text { atau } 84,8 \%
\end{aligned}
$$


Hasil perhitungan ketepatan model sebesar 86,2\% menerangkan bahwa kontribusi model untuk menjelaskan hubungan struktural dari lima variabel yang diteliti adalah sebesar $84,8 \%$ dan sisanya sebesar $15,2 \%$ dijelaskan oleh variabel lain yang tidak dimasukkan dalam model.

\section{Pengaruh disiplin kerja Terhadap motivasi Kerja}

Hipotesis yang menyatakan bahwa disiplin kerja berpengaruh secara langsung terhadap motivasi kerja karyawan siqnifikan. Hal ini dibuktikan oleh hasil uji regresi dimana probabilitas (p) lebih kecil dari 0,05 yang berarti signifikan. Artinya disiplin kerja mempunyai pengaruh nyata terhadap motivasi kerja karyawan. Besarnya koefisien path (PY1X1) sebesar 0,494 mengindikasikan pengaruh disiplin kerja bagi karyawan PT. Indosatooredo, Tbk Bandar Lampung terhadap motivasi kerja adalah positif. Artinya segala upaya membudayakan disiplin kerja terhadap karyawan yang mendapat tanggapan positif akan menjadi faktor pendorong semakin tingginya motivasi kerja karyawan. Setiap karyawan dalam menjalankan pekerjaannya seharusnya dapat menumbuhkan rasa tanggungjawab dengan aktifitas yang dilakukan. Disiplin kerja bagi karyawan merupakan hal yang sangat penting untuk memotivasi karyawan dalam melaksanakan tugasnya. Dampak disiplin kerja terhadap motivasi kerja karyawan akan semakin meningkatkan hasil kinerja karyawan dalam perusahaan.

\section{Pengaruh Disiplin kerja Terhadap Kinerja Karyawan.}

Hipotesis yang menyatakan bahwa disiplin kerja berpengaruh langsung terhadap kinerja karyawan terbukti. Hal ini dapat dilihat dari uji regresi dimana probabilitas (p) lebih kecil dari $\alpha=0,05$ yang berarti signifikan. Artinya disiplin kerja mempunyai pengaruh langsung yang bermakna terhadap kinerja karyawan. Besarnya koefisien path (PY2X1) sebesar 0,234 dan signifikan menunjukkan bahwa kinerja karyawan bisa dijelaskan secara langsung oleh disiplin kerja. Kinerja karyawan yang tinggi timbul sebagai dampak dari disiplin kerja yang dilaksanakan atau dibudayakan oleh para karyawan.Hasil analisis jalur menerangkan bahwa kinerja karyawan sangat dipengaruhi disiplin kerja yang diterapkan oleh karyawan perusahaan.Hasil ini sejalan dengan penelitiannya Sidanti (2015) dan Hidayat dan Taufiq (2012) yang menyimpulkan bahwa ada pengaruh yang signifikan antara disiplin kerja terhadap kinerja karyawan.

\section{Pengaruh Kemampuan Terhadap motivasi Kerja}

Hipotesis yang menyatakan bahwa variabel kemampuan berpengaruh nyata terhadap variabel motivasi kerja. Hal ini dibuktikan oleh hasil uji regresi dimana probabilitas (p) lebih kecil dari $\alpha=0,05$ yang berarti signifikan. Artinya kemampuan mempunyai pengaruh yang positif terhadap variabel motivasi kerja karyawan. Besarnya koefisien path (PY1X2) sebesar 0,375, mengindikasikan pengaruh variabel kemampuan karyawan PT. Indosatooredo, Tbk Bandar Lampung terhadap motivasi kerja adalah berpengaruh positif. Artinya kemampuan karyawan sangatlah penting untuk menumbuhkan 
dan memacu motivasi bekerja yang pada akhirnya dapat meningkatkan hasil kinerja karyawan pada perusahaan.

\section{Pengaruh Insentif Terhadap motivasi Kerja}

Hipotesis yang menyatakan bahwa variabel insentif berpengaruh langsung terhadap motivasi karyawan terbukti. Hal ini dapat dilihat dari uji regresi dimana probabilitas (p) lebih kecil dari $\alpha=0,05$ yang berarti signifikan. Artinya insentif yang diberikan perusahaan mempunyai pengaruh nyata yang bermakna terhadap motivasi karyawan. Besarnya koefisien path (PY1X3) sebesar 0,135 dan signifikan menunjukkan bahwa motivasi karyawan bisa dijelaskan secara langsung oleh variabel insentif. Hasil ini sejalan dengan penelitiannya Ulfa, dkk (2013) ) yang menyimpulkan bahwa ada pengaruh yang signifikan antara intensif terhadap motivasi karyawan. Motivasi karyawan yang tinggi timbul sebagai dampak dari pemberian insentif oleh perusahaan sebagai penghargaan prestasi yang sudah ditunjukkan oleh karyawan.

\section{Pengaruh Insentif Terhadap Kinerja Karyawan}

Pengujian Hipotesis yang menyatakan bahwa insentif berpengaruh langsung terhadap kinerja karyawan terbukti. Hal ini dapat dilihat dari uji regresi dimana probabilitas (p) lebih kecil dari $\alpha=0,05$ yang berarti signifikan. Artinya insentif mempunyai pengaruh langsung yang bermakna terhadap kinerja karyawan. Besarnya koefisien path (PY2X3) sebesar 0,485 dan signifikan. Hal ini menunjukkan bahwa kinerja karyawan bisa dijelaskan secara langsung oleh variabel intensif. Kinerja karyawan yang tinggi timbul sebagai dampak dari pemberian intensif oleh perusahaan kepada para karyawan. Hasil analisis jalur menerangkan bahwa kinerja karyawan sangat dipengaruhi variabel insentif yang diterapkan oleh perusahaan. Hasil ini sejalan dengan penelitiannya Fauziah (2012) dan Martcahyo (2012) yang menyimpulkan bahwa ada pengaruh yang signifikan antara variabel insentif terhadap kinerja karyawan.

Pada prinsipnya insentif adalah imbalan yang diberikan kepada seorang karyawan yang melakukan suatu pekerjaan diluar tugas pokoknya atau melebihi target dari pekerjaan yang menjadi tugasnya (Bachrun, 2011 : 22). Jackson dkk (2011 : 192) mengatakan pembayaran insentif adalah pembayaran yang dilakukan untuk satu kali untuk setiap penghargaan. Pembayaran insentif memberikan kesempatan untuk memperoleh jumlah upah berbasis kinerja yang lumayan besar. Pengupahan insentif dimaksudkan untuk memberikan upah/gaji yang berbeda karena memang prestasi kerja yang berbeda (Ardana dkk, 2011 : 169).

\section{Pengaruh Motivasi Terhadap Kinerja Karyawan}

Pengujian Hipotesis yang menyatakan bahwa motivasi berpengaruh langsung terhadap kinerja karyawan terbukti. Hal ini dapat dilihat dari uji regresi dimana probabilitas (p) lebih kecil dari $\alpha=0,05$ yang berarti signifikan. Artinya variabel motivasi mempunyai 
pengaruh langsung yang bermakna terhadap kinerja karyawan. Besarnya koefisien path (PY1Y2) sebesar 0,175 dan signifikan. Hal ini menunjukkan bahwa kinerja karyawan bisa dijelaskan secara langsung oleh variabel motivasi. Kinerja karyawan yang tinggi timbul sebagai dampak dari adanya motivasi karyawan dalam bekerja. Hasil analisis jalur menerangkan bahwa kinerja karyawan sangat dipengaruhi variabel motivasi yang dimiliki para karyawan. Hasil ini sejalan dengan penelitiannya Hidayat dan Taufiq (2012) dan Sajangbati (2013) yang menyimpulkan bahwa ada pengaruh yang signifikan antara variabel motivasi terhadap kinerja karyawan.

Seorang yang memiliki motivasi yang rendah mereka cenderung untuk menampilkan perasaan tidak nyaman dan tidak senang terhadap pekerjaannya. Sehingga semakin besar motivasi yang dimiliki oleh individu sebagai karyawan dapat meningkatkan kinerja karyawan itu sendiri. Kurangnya motivasi kerja dari pimpinan untuk karyawan perusahaan akan menghambat kinerja karyawan dan juga membuat suasana kerja tidak Disini terjadinya motivasi yang kurang terarah pada karyawan oleh pemimpin, disini kurang terarah dimaksudkan dengan kurangnya motivasi yang diberikan oleh pemimpin terkadang tidak sesuai dengan prestasi kerjanya, dimana jika pemimpin yang mempunyai motivasi berpretasi tinggi cenderung memiliki prestasi kerja tinggi dan sebaliknya, mereka yang prestasi kerjanya rendah dimungkinkan karena motivasi prestasinya juga rendah. Motivasi dapat mendorong karyawan bekerja dengan tekun, serta disiplin dalam bekerja sehingga dapat tercapai tujuan perusahaan yaitu menciptakan suasana kondusif terhadap lingkungan kerja perusahaan. Setiap karyawan belum tentu bersedia mengerahkan kemmapuan yang dimilikinya secara optimal, sehingga masih diperlukan adanya dorongan dari pihak luar, untuk itu agar bisa menumbuhkan motivasi kerja dalam suatu organisasi dibutuhkan suatu komunikasi yang intensif antara karyawan dengan pimpinan maupun antar sesama karyawan.

\section{SIMPULAN DAN SARA}

Berdasarkan hasil penelitian yang telah diuraikan, maka kesimpulan yang diperoleh adalah disiplin kerja mempunyai pengaruh positif dan signifikan terhadap motivasi kerja PT. Indosatoredo, Tbk Bandar Lampung. Hal ini berarti semakin disiplin karayan maka motivasi karyawan PT. Indosatoredo, Tbk Bandar Lampung akan meningkat. Sedangkan variabel kemampuan karyawan juga mempunyai pengaruh positif terhadap motivasi kerja, sehingga untuk meningkatkan motivasi karyawan terus meningkat perusahaan PT. Indosatoredo, Tbk Bandar Lampung harus terprogram dan terencana dengan baik untuk meningkatkan kemampuan kaeryawannya.

Disiplin mempunyai pengaruh positif dan signifikan terhadap kinerja karyawan PT. Indosatoredo, Tbk Bandar Lampung. Hal ini berarti disiplini yang tinggi akan dapat meningkatkan kinerja karyawan. Kemampauan mempunyai pengaruh positif dan signifikan 
terhadap motivas PT. Indosatoredo, Tbk Bandar Lampung. Hal ini berarti, semakin tinggi kemampuan karyawan maka akan mendorong motivasi karyawan semakin meningkat untuk berkerja. Insentif mempunyai pengaruh positif dan signifikan terhadap motivasi karyawan PT. Indosatoredo, Tbk Bandar Lampung . Hal ini berarti insentif yang diberikan kepada karyawan secara adil akan dapat meningkatkan motivasi kerja karyawan.

Insentif mempunyai pengaruh positif dan signifikan terhadap kinerja karyawan PT. Indosatoredo, Tbk Bandar Lampung. Hal ini berarti semakin sering insentif diberikan sebagai penghargaan dari prestasi kerja akan mendorong dan meningkatkan kinerja karyawan pada perusahaan. Motivasi mempunyai pengaruh positif dan signifikan terhadap kinerja karyawan PT. Indosatoredo, Tbk Bandar Lampung. Hal ini berarti semakin termotivasi karyawan maka akan menciptakan hubungan yang baik antar karyawan PT. Indosatoredo, Tbk Bandar Lampung akan meningkat.

Berdasarkan kesimpulan tersebut, maka saran yang dapat disampaikan adalah pihak perusahaan harus menerapkan disiplin kerja, meningkatkan kemampuan karyawan dan sekaligus memberikan penghargaan sebagai insetif dengan baik sehingga dapat mendorong motivasi kerja dan sekaligus akan meningkatkan kinerja karyawan dalam bekerja di perusahaan. Perusahaan sebaiknya terus melakukan dan menumbuhkan motivasi terencana dan terus menerus terhadap para karyawansehingga karyawan selalu termotivasi dan tetap bekerja lebih baik dalam perusahaan, sehingga dampak akhirnya kinerja karyawan dapat selalu ditingkatkan dan terjaga dengan baik. Penelitian ini diharapkan dapat menjadi refrensi bagi PT. Indosatoredo, Tbk Bandar Lampungi dalam upaya meningkankan kinerja karyawan demi keberlangsungan perusahaan itu sendiri. Bagi penelitian selanjutnya diharapkan mampu mengembangkan model penelitian ini dengan menambahkan variabel lain yang mempengaruhi kinerja karyawan selain disiplin, kemampuan, intensif, dan motivasi yang didukung dengan teori dan isu-isu terbaru. Peneliti selanjutnya juga diharapkan untuk memperluas ruang lingkup wilayah penelitian dan lokasi penelitian sehingga hasil penelitian dapat diimplementasikan secara umum.

\section{REFRENSI}

Ardana, Komang, Ni Wayan Mujiati, I Wayan Mudiartha Utama. 2012.Manajemen Sumber Daya Manusia. Yogyakarta : Graha Ilmu

Bachrun, Saifuddin. (2011). Menghitung Tunjangan, Insentif, Bonus dan Fasilitas dalam Praktik. Jakarta : Penerbit PPM. 
Fauziah, H. 2012. Pengaruh Insentif dan Motivasi Kerja Terhadap Kinierja Pegawai Pada Kantor Dinas Bina Marga Balai Besar Pelaksanaan Jalan Nasional III Satker Pelaksanaan Jalan Nasional Wilayah Bandar Lampung. https://s3. amazonaws.com/academia.edu. documents/37149987/7-hujaimatul-fauziah.pdf? AWSA ccessKeyId =AKIAIWOWYYGZ2 Y53UL3A\&Expires $=1529418052 \&$ Signature $=\% 2 \mathrm{BO} \% 2 \mathrm{BjnzcrXKgJ6A} \% 2$ FkfSSpH3 vym0\%3D\&response-contentdisposition=inline $\% 3 \mathrm{~B} \% 20$ filename $\% 3$ Dhujaimatul_Fauziah _Pengaruh_ insentif_ dan.pdf

Hasibuan. Malayu S.P (Eds). 2013. Manajemen Sumber Daya Manusia. Jakarta: PT. Bumi Aksara

Hidaya, Zainul dan Taufiq, Muchamad. 2012. Pengaruh Lingkungan Kerja dan Disiplin Kerja serta Motivasi Kerja Terhadap Kinerja Karyawan Perusahaan Daerah Air Minum (PDAM) Kabupaten Lumajang. http://ejournal. Stie widyagama lumajang.ac.id/ index.php/ wiga/article/ view/64/73

Jackson, Schuler, Werner. (2011). Pengelolaan Sumber Daya Manusia (10th ed.). Jakarta : Salemba Empat

Mangkunegara, Anwar Prabu. 2013. Manajemen Sumber Daya Manusia. Bandung: PT. Remaja Pasda Karya.

Martcahyo, VA, Hidaya, W, dan Suryoko, S. 2013. Pengaruh Pelatihan Kerja, Jaminan Sosial, dan Intensif Terhadap Kinerja Karyawan Bagian Produksi PT. FUMIRA Semarang. https://scholar.google.co.id/scholar?start=90\&q=pengaruh+insentif + terhadap +motivasi+karyawan\&hl=id\&as_sdt=0,5

Mulyadi. 2015. Manajemen Sumber Daya Manusia (MSDM). Bogor: Penerbit IN MEDIA

Moeheriono. Dr. (Eds). 2 012. Pengukuran Kinerja Berbasisi Kompetensi. Jakarta: Rajawali Pers.

Nurcahyo, Anyon. 2011. Analisis Variabel-Variabel Yang Mmempengaruhi Kinerja Karyawan Pada PT. Quadra Mitra Perkasa Balikpapan. Jurnal Eksis, Volo.7(2), $1816-2000$

Sajangbati, Ivonne AS. 2013. Motivasi, Disiplin, dan Kepuasan Pengaruhnya Terhadap Kinerja Pegawai PT. POS INDONESIA (PERSERO) Cabang Bitung. https://ejournal.unsrat.ac.id/index.php/emba/article/viewFile/2750/2303

Sidanti, Heny. 2015. Pengaruh Lingkungan Kerja, Disiplin Kerja, dan Motivasi Kerja Terhadap Kinerja Pegawai Negri Sipil Di Sekretariat DPRD Kabupaten Madiun. Madiun http://lp3m.asia.ac.id/wp-content/uploads/2012/10/7-JURNAL-HENY-SMADIUN-JIBEKA-VOL-9-NO-1-FEB-2015.pdf

Sugiyono. 2013. Metode Penelitian Bisnis. Bandung: Alfabeta.

Sugiyono. 2015. Metode Penelitian Bisnis. Bandung: Alfabeta. 
Suprihati. 2014. Analisis Faktor-Faktor Yang Mempengaruhi Kinerja Karyawan Perusahaan Sari Jati di Sragen. Jurnal Paradigma. Vol. 12(01),93-119

Sutrisno, Edy. (Eds). 2014. Manajemen Sumber Daya Manusai. Jakarta: Kencana Prenada Media Grup

Syachroni. 2013. Analisis Faktor-Faktor Yang Mempengaruhi Kinerja Karyawan Guru SMA Negri 4 Kota Jambi. Jurnal Dinamika Manajemen . Vol.1(2),121-138

Ulfa, M, Ruhana, KR. 2013. Pengaruh Kompensasi Terhadap Motivasi Kerja Dan Kinerja Karyawan (Studi pada Karyawan Auto 2000 Malang Sutoyo) http://administrasibisnis. studentjournal.ub.ac.id/index.php/jab/article/ viewFile/ $123 / 211$

Wibowo. Dr. (Eds). (2015). Prilaku dalam Organisasi. Jakarta: PT. Raja Grafindo Persada 